\title{
ETHICS INVOLVED IN THE HANDLING OF PERSONAL PAPERS ${ }^{1}$
}

\author{
By Edgar R. Harlan
}

As a rule the product of the pen is the property of the writer. This property may be taken from him only with the knowledge and consent of the producer or his vendee. But the product, when the result of public service is the property of the public, is subject to exclusive public control. Its disposition is for the administrative head of a proper governmental unit. And as the product of a writer who is a public agent is public property, so is that of the agent of a corporation the property of the corporation, and the product of the agent of an individual is the property of his principal. Secrecy in public, quasi public and private relations, is for the election of the principal until such electon is affected in a court of competent jurisdiction. The right thus to control follows into all products of the pen until the rights of third persons become involved.

Writings that exist beyond the lives of the writers retain their property character with relative interests of the writer and others. In no jurisdiction or province of ethics is there, actual or implied, a statute of limitations upon this character or qual. ity. The original right of the writer remains and continues after his death.

The writer has not only the absolute and perpetual right of . disposition of his product; he has the perpetual protection of the courts and of ethics in this right. But there is a distinction between the thoughts included in a writing, the zoriting itself, and the paper bearing the inscription.

Productions of the pen in the control of the Historical, Memorial and Art Department of Iowa are literary and scientific manuscripts, or public or personal missives that are usually denominated letters. Literary manuscripts are private in the absence of specific directions of the producer to the contrary: until their delivery for a consideration, or of their publication

1Read in part at the Des Moines meeting of the Mississippi Valley Historical Association April 26, 1028. Acknowledgments to West Publishing Co., Saint Paul, for legal rẹerences. 
by printing or otherwise. Copyright of such writings is applied in ethics and in law throughout and beyond the life of the writer.

It was probably Plato, $400 \mathrm{~B}$. C., who first drew the specification of ethical procedure. It was no doubt then an ancient settled principle: "Dealings between man and man require to be suitably regulated. The principle then is very simple. Thou shalt not touch that which is mine, if thou canst help, or remove the least thing which belongs to me without my consent; and may I, being of sound mind, do to others as I would they should do to me." So if we, being honest, would restore to its owner a lost purse, we as trustees should also, remaining honest, restore to a writer the last mede of value, pecuniary or literary.

Repositories of papers whether transmitted to or received by individuals are embraced in both law and ethics. As such custodian the Historical, Memorial and Art Department stands ready to retain and administer any item precisely as the original owner would or should have done, or to return our exotic items to their proper native localities." There is one condition: The requisitioning administration and repository must be equal in efficiency and permanence, in the judgment of our institution. to that of our own. We voluntarily proceed as a court would probably order.

\section{Custody of Public Arcinges}

As repository and custodian of the public archives of Iowa: the Curator of our institution is by law empowered to possess and control public manuscript materials with the same authority the functionary had under whose hand they originated. Moreover, he is empowered to certify in the same manner and to the same effect as the originating authority. Under seal of the Curator they are admissible in our courts the same as under the seal of the originating office. ${ }^{3}$ These rights and responsibilities, by the Curator, with the approval of the Board of Trustees, have been extended into our collection of newspapers; of private papers and object materials; of unique and extra va! uable books. The purpose of the Curator, in addition to this effort to continue the presumed prudence of originating persons and officials, embraces a record of applications for, and purpose of the use of

2See Annual Report Am. Hist. Soc, 1914, Vol. 1, p. 319 ; ibid., 325; ibid., 371. 3Chip. 233, Corle of 1927 , Sec. $4529,4530,4531$, 
materials, and the applicant's report of service we render. 'The utility and public value of the collections are thus revealed. These data, carried into the proper catalogue, are growing into a most valuable reference repository. For fuller information the public is referred to a volume by Mr. C. C. Stiles, director of archives, which our institution published in $1928 .^{*}$

\section{Private Archives}

Among the most delicate and important of our functions is that of handling the manuscript collections of private individuals. These collections have single items in scores, and almost millions in a few instances. ${ }^{5}$ In the absence of a standardized term for such collections we allude to them as private archives. Their potential uses are innumerable, their value incalculable. Each rests in its integrity in the same confidential status it enjoyed under the living hand of its original owner. Many are underlaid by memoranda limiting the uses to which they may be put. In some instances the institution is charged, in general terms, to prevent their use to the damage of anyone, with implied liability on the institution for indiscretion.

There is often an overlapping of public and personal zones. John F. Lacey's file from 1859 to 1913 flows through the life of a student, a soldier, a lawyer, a legislator in the Iowa General Assembly and United States House of Representatives, an active member of the Iowa Grand Army of the Republic, a noble husband and indulgent father. Hence the constant obligations in ethics common to the donor of the Lacey papers, the Curator and the applicant for the use of the materials. They are mutually bound, first by law, next by conditions of deposit, and finally by the ethics of confidential communication.

The more is this true since, of the millions of these private missives, not more than twenty per cent are the production of individuals from whom they were secured. Their own missives, if in existence, are in the repositories of their correspondents. Hence each original owner was bound to regard himself as trustee for the proper use of any one of the letters received, and with us those who may use them are so bound.

\footnotetext{
4Public Archives: A Manual for their Administration in Iowa, 1928.

5See appendix for complete alphabetical Jist of thẹ cọlleçtions as of April 1,1029 .
} 
There arises the interesting and most vital question, whether a missive in possession, but not the product, for instance, of William B. Allison, was his property or that of the one who composed and transmitted it to him. We are presumed to know all that went through Allison's mind. If he ever granted a request for use of thought written to him did he first obtain the consent of the one who wrote and of the one transmitting it? Did he have or assume the right and responsibility of delivering a missive he received only for his own public or private use? Did he for his own protection, when applied to for use of such material, require to know, so as to judge of the propriety of, the nltimate use? If he was aware of the use intended and approved of it, did he suggest or withhold information of other and like materials in his own repository or elsewhere? Finally, did he exercise his own judgment as to requiring credit to be given or responsibility to be assumed for the use of thoughts not his, for which he was in part responsible, or did he delegate the decision to the applicant? These and many other questions of the rights and privileges of those who produce, those who receive, and those who shall use, arise in every instance of administration of our private archives.

\section{The Law of Private Archives}

While there is a century of precedents in British and American jurisprudence, determining rights of those who produce, those who privately receive, and those who make use of privately written communications, there are apparently none determining rights or responsibilities of their public custodians. Questions have been determined and judginents rendered in suits between writer and recipient upon many phases of property rights-such as of libel and slander, of implied and expressed sanctity of confidence, of the limitation of time during which transmitted statements remain vital. None seems to alter relations, by the physical transfer of custody to a public repository, confers no authority nor immunity not that of the private recipient.

Scores of questions of common ethics have been determined. To mention in effect, a few: In England James Abbott McNeill Whistler, the celebrated artist, having written letters believed to be useful by his biographer, the biographer was forbidden by 
Mrs. Whistler to use certain of them. The court held that the biographer was entitled, without express authority, to use the information contained in the letters, but that neither the letters, extracts therefrom, nor paraphrases, might be published. ${ }^{6}$

In New York the writer of a letter, whether of a literary character, a familiar, business or other type of communication, retains the sole and exclusive right to publish, and without his consent none might be published by those to whom it was addressed or by any other unless for the vindication of the rights and conduct of the one receiving it. A stranger possessing letters or copies thereof unlawfully, has no. right to publish for any purpose whatsoever. ${ }^{7}$

In the same state neither business nor private letters received by an individual and in his hands at his death are held to have a character of assets and, therefore, are not subject to sale or assignment. ${ }^{8}$

In Massachusetts an author has an exclusive copyright to his letters unless he unequivocally dedicate them to the public or to some private person, and no one may publish them without his consent except to establish a personal right or to vindicate character. Historians may remember the publication of the Upham Life of Washington of 866 pages, where 353 of those pages were copied from Sparks's Life and Writings of Washington, 64 pages being official letters of Washington, originally published by Mr. Sparks under contract of the owner from the original papers of Washington. The publication was held to be an invasion of Sparks's copyright.

In the same state it was further held that the right of an author to publish or to suppress publication of his correspondence is absolute in the absence of special considerations and is independent of any desire or intent at the time of the writing. It is an interest in the intangible and impalpable thought and the particular verbal garments in which it has been clothed. Independent of the manuscripts this right involves a right to copy or to secure copies, otherwise the author's right of publication might be lost. The author parts with the physical and material

6Philip v Pennell, 2 Chan., (1907) 577.

7Woolsey y Judd et nl, 11 Howard's Practice Reports, 49.

8Eyre v Hipbee, 22 Howard's Practice Reports, 198.

gFolsom v Marsh (C. C. Dist., Mass.) Fed. cases No. 4901. 
elements which are conveyed by and in the envelope. These are given to the receiver. The paper upon which the letter is written belongs to the receiver. A duty of preservation would impose an unreasonable burden in most instances. It is obvious that no such obligation rests upon the receiver, and he may destroy or keep at pleasure. Commonly there must be inferred a right of reading or showing to a more or less limited circle of friends and relatives. But in other instances the very nature of the correspondence may be such as to act as the seal of secrecy upon its contents. Letters of extreme affection and fiduciary communications may come within the class. There may be also a confidential relation existing between the parties, out of which would arise an implied prohibition against any use of the letters, and a breach of such trust might be restrained in equity. He can deal with it as absolute owner subject only to the proprietary rights retained by the author himself and his representatives to the publication or nonpublication of ideas in its particular verbal expression. ${ }^{10}$ And it is interesting, if less important to the historian, to extend this principle to enclosures, such as clippings and pictures.

Although it can be said that rules identical with these principles have not been established by the courts in all states, nothing in Iowa is at variance with their trend. Therefore our institution stands in law and in ethics in each case in the shoes of the individual who originally received as well as him who deposited with us the missives. Such discretion as was theirs passed to the Curator under the authority of his Buard of Trustees.

As the opinion of no court of last resort seems to have been rendered in our jurisdiction upon the status of a repository such as ours, the points settled having been in litigation as between those who sent and those who received the missives, or their legal representatives, the Curator of the Historical, Memorial and Art Department of Iowa proceeds under the above principles as if he were the original recipient of the private archives. Though in public office, he is a mere trustee of private property bound to decide in each instance upon the merit of each applicant, and

10Baker v Libby (Mass.) 97 N. E., 109. 
to accept the risk of his act. His mode of operating is revealed in the following forms:

\section{RULES AND CONDITIONS}

Every request for the privilege to inspect or to use any of these materials will be regarded as a public request and will be granted, as a matter of course, if in litigation the request might be enforced as a matter of right by subpoena duces tecum. All other requests will be regarded as private requests.

Each private request to inspect or to use one or more items will be granted, where the applicant is known to the Curator to be capable and responsible, and it is also shown to him that the privilege if granted may promise a creditable addition to historiçal information.

All requests whether public or private must be in writing, signed by the applicant and, when he is unknown, vouched for by his sponsor, and shall substantially conform to the application required in a court of record for an order to produce books or papers.

EDGAR R. HARLAN,

Curator.

\section{REQUEST}

Historical Department of Iowa Des Moines, Iowa.

Edgar R. Harlan, Curator, Historical, Memorial and Art Department of Iowa. $.19 \ldots$ Sir :-

I respectfully request the privilege of inspecting the personal papers

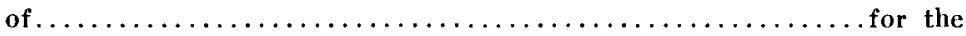
years of ............................. thelusive for the specific

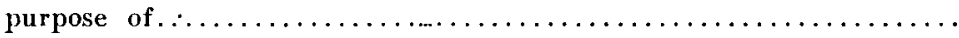

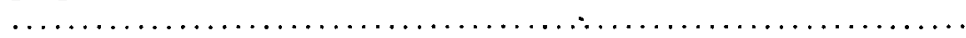

The items will be quoted verbatim, abstracted or adapted and so accredited as you will approve.

I represent the. and attach hereto my credential therefrom

Also as a private individual $I$ assert my motive and purpose are serious, important and for the public good. I hereby guarantee all uses to be made of the privilege sought shall be free from malice, error and implications tending to offend, slander or libel and I warrant you and the Historical Department that no complaint, action or penalties will ever grow out of the grant of the privilege.

Upon the representation above and solely within their literal terms

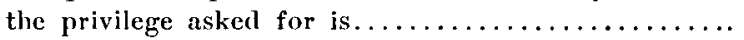


The ready co-operation with us under our system by a noted research expert for a forthcoming biography of one of Senator Allison's closest and most powerful associates, illustrates the advantage of our system to that important work. Our rule that we shall see the proof, pass upon the accuracy of quotations and citations, enabled us to offer some thirty vital corrections and amendments. Passing upon the propriety of the quotations we found but a single instance for suggestion, and it was cordially accepted. These points which we checked and certified, amounting to some forty, were cited by the author from many thousands of the Allison letters. One citation only were we unable to verify. The missive referred to could not be found. We attribute that fact to a probable misplacement by some one of the many searchers who have used the collection after this author had completed her search. We are, therefore, in the spirit of our system, obliged to go entirely through the liundreds of thousands of Allison letters in order to supply it or to certify that the item does not remain in the collection.

We have been applied to for the use of our personal archives by historians, economists, attorneys, fiduciary agents and probate officials. None have been unwilling or reticent to comply with our policy. None have complained to us concerning the collections or their administration.

\section{Appendix}

Alphabetical List of Manuscript Collection in the Historical, Memorial and Art Department of Yowa, as of April 1, 1929.

Abercrombie, John C.

Abernetly, Alonzo

Abraham, Lot

Abrams, J.

Adams, Mary Newberry

Aldrich, Charles

Aldrich, 'Thomas Bailey

Algona Bee

Allingham

Allison, William Boyd

Allyn, Matthew

Amos, Emma

Andrews, H. F.

Ankeny, Harriett Louise

\author{
Ankeny, Joseph \\ Anson, 'Thomas \\ Armistrong, Frank \\ Audubon, Jolın James \\ Avery, William \\ Bailey, A. S. \\ 13ailey, Gideon $\mathbf{S}$. \\ Baker, Nathaniel $B$. \\ Baldwin, W. W. \\ Baring-Gould \\ Barker, H. H. \\ Barker, Noah \\ Bartlett, Maro L. \\ Barton, Clara
}


Beach, Abel

Beaumont, Abbey Louisa

Beck, J. M.

Beckwith, Zenas and wife

Beecher, Henry Ward

Belknap, W. W.

Benton, Thos. H., Jr.

Berryhill, Jas. G.

Birge, Charles $P$.

Bloomer, Dexter C.

Bowers, H. F.

Bradfield, Adolphus

Briggs, Ansel

Briggs, Minerva

Brigham, Johnson

Brindley, J. E.

Briston, Pierson $\mathrm{H}$.

Bristow, J. E.

Brockway, E. F.

Brooks, Phillips

Brown, Hugh

Brown, Leonard

Buddhist Mss.

Busby, Alice B.

Bussey, Cyrus

Byers, S. H. M.

Cadle, Richard

Caldwell, Henry Clay

Callanan, Martha

Callen, Martin and Jane

Campbell, William $\mathbf{H}$.

Carpenter, Cyrus C.

Casady, P. M.

Case, A. and Mary

Catlow, Maria E.

Chambers, John

Clark, Charles A.

Clark, Everett

Clarke, F. G.

Clarke, William Penn

Clarkson, James S.

Cleveland, Grover

Clodd, Edward

Cloutman, Charles C.

Clute, Oscar

Cole, C. C.

Cook, Andrew
Coppersmith, George

Coppoc, Barclay

Coughlan, Richard

Cousins, Robert G.

Crabbe, George

Cratty, R. I.

Crawford, F. Marion

Crocker, Marcellus M.

Croghan, George

Cummings, H. J. B.

Cummins, A. B.

Curtis, E. W.

Curtis, Samuel R.

Dahlberg, R. N.

Dailey, Rebecca

Davenport, George

Davis, Edward Cox

Davis, Jefferson

Davis, Sarah

Davis, Varina

Deemer, Horace E.

Des Moines City S. S. Shipping Bill

Des Moines Clearing House Association

Des Moines East High School

Des Moines House Register, 1864

Des Moines Presbyterian Church

Des Moines Presbytery

Des Moines River Front Buildings

Des Moines River Front Improvement

Des Moines River Land

Des Moines St. $\Lambda$ mbrose Bapt. Reg. 1858

Des Moines School Census, 1912

Des Moines Union League (East)

Des Moines Valley

Des Moines Valley, R. R.

Devere, Aubrey

Devoe, D. D.

Dilke, Charles

Dillon, John F.

Dobson, Austin

Dodge, A. C.

Dodge, Grenville $M$.

Dodge, Henry

Dolliver, J. P. 
Downey, H. D.

Downing, Alexander $\mathrm{G}$.

Drake, Francis Marion

Drike University

Dubuque Clubs

Dubuque Conversational Club

Dubuque Female College

Dubuque Railway

Dubuque Typographical Union

'Treasurer's Book

Duckworth, John A.

Duels in Early Times

Dutton, Celinda Parker

Dutton, Jerome

Eaton, A. K.

Edwards, John

Ellison, G. D.

Ellwood, J. M.

English, Thomas Dumn

Eriesson, John

Evans, Robley D.

Evans, W. C.

Felch, I.evi

Field Notes, Indian Treaties

Fleming, William $\mathrm{H}$.

Ford, Daniel

Forman, Samuel S.

Foster, C.

Foster, John C.

Foster, William Davis

Freeman, Edward A.

Fugitive Slave, Warrant for

Fullenwider, Samuel

Fuller, Corydon E.

Fuller, Cor

Galland, Washington

Gallitzin, Demetrius Augustine

Garfield, James A.

Garland, Hamlin

Garst, Warren

Gayarre, Charles

Gilham, James G.

Gillette, C. L.

Gmelin, Henry C.

Goddard, Ed

Gower, Robert

Gowey, Ann
Grange Papers

Granger, Barlow

Granger, H. F. and "Bert"

Grant, James

Grant, U. S.

Green, H. H.

Grier, William H.

Griffith, H. H.

Grimes, James W.

Gue, Benjamin F.

Haeckel, Ernst

Hall, James

Hamilton, Edw. J.

Hamilton, W. E.

Hamline, Leonidas L.

Hammond, William A.

Hanford, Cornelius $\mathrm{H}$.

Harlan, James

Hartsook, Jas. R.

Heffelfinger, Jacob

Hempstead, Stephen

Henderson, P. P.

Henry, Archibald R.

Herriott, F. I.

Hill, James L.

Hitchcock, E. A.

Hockersmith, John

Holland, William

Hough, Emerson

Hough, Peter

Howard, Thomas $O$.

Hubbard, Elbert

Hughes, Rupert

Huntington, Ida M.

tHussey, Tacitus

Ingham, S. W.

Iowa Baptist Education

Iowa Hall of Fame

Iowa Seal-Territorial and State.

Iowa State Grange

Iowa State Park-The Backbone

Ives, S. P.

Jackson, Frank D.

Jacobs, Austin and Dyer, Charles

James, Henry

Jewett, Sarah Orne

Johnston, Benjamin 
Jones, Bertrand

Jones, George W.

Jordan, J. H.

Jeuttner, Otto

Kasson, John $\mathbf{A}$.

Keck, J. A.

Keith, Isham

Kellogg, Harriette S.

Kempker, J. F.

Keyes, C. W.

Killbourne, D. W.

King, Grace

Kinney, J. F.

Kirkwood, Samuel J.

Knapp, Herman

Kneeland, Abner

Lacey, John F.

Landers, Frank E.

Lands: Muniments of Title

Langstroth, L. L.

Larrabee, William

Latchaw. J. H.

Latin Mss. 1619

Lauman, Jacob Gartner

Lawrence, George N.

Lee, George R.

Leland, Charles Godfrey

Letcher, John

Levi, A.

Lewis, Dwight

Libby Prison-Letter from

I.jincoln, Abraham

Lister, John S.

Lombard Univers

Looby, John $\mathbf{H}$.

Loughridge, 'Albert

Lyon, Robert E.

MeArthur, W. C.

McClure, George

McCrary, George W.

McCreery, J. L.

Mackay, Wallace E.

McKean, Thomas $J$.

McMaster, John Bach

McMillan, E. C.

McNutt, Samuel

McPherrin, Andrew
MacVicar, John

Macy, Jesse

Malcolm, A. H.

Manning, Orlando $\mathrm{H}$.

Maple, William $\mathrm{H}$.

Marvin House, Reg. 1854

Mason, Charles

Matson, Sylvester G.

Melendy, Peter

Merrill, Samuel

Merritt, Darwin

Mikesell, William

Miles, Lewis

Miller, Daniel

Misc. Papers, singles

Mitchell, Bennet

Moore, S. A.

Moorhead, John

Morgan, Thomas

Morris, William

Mueller, Frederick von

Muller, Max

Neuhring, Henry

Nicolay, John G.

Noble, John W.

Nourse, C. C.

Oneida Conference Seminary

Ordnay, Clarence S.

O'Reilly, Henry Brooks

Ormsby, James B.

Otis, J. M.

Packard, Stephen B.

Palmer, Frank W.

5 Pammel, L. H.

Parker, George F.

Parry, C. C.

Parsons, Theophilus

Parvin, T. S.

Pearman, John W.

Pearson, Benjamin F.

Pence, Gabriel and John

Phillips, William

Powell, J. R.

Prairie Club

Price, Hiram

Probst, George

Quick, Herbert 
Randall, James $\mathbf{R}$.

Redfield, James M.

Reed, D. W.

Reid, Harvey

Remey, George C.

Remey, Mary J.

Revolutionary War Mss.

Rice, Samuel

Richards, Seth

Roberts, Alfred

Roosevelt, Theodore

Rosetti, William M.

Ruckman, E. B.

Rush, John W.

Russell, John

Sabin, Henrȳ

Salter, William

Saunders, Charles G.

Savage, William

Savery, Annie M.

Sawvel, Adam

Sayse, A. H.

Schermerhorn, Zella

Schrader, John Jacob

Scott, O. H. P.

Sellers, A. A.

Seward, Wm. H.

Shaffer, Joshua M.

Shaw, Leslie Mortier

Shaw, William Tuckerman

Sherman, Buren R.

Sherman, John

Sherman, William Tecumseh

Silket, Geo. W.

Skinner, T. B.

Smith, Lewis Worthington

Sommers, C. E.

- Spaulding, M. C.

Spirit Lake Monument

Spry, Wm.

Stanard, Edward O.

Stanton, E. M.

Stanwood, Harry

Stern, Millicent B.

Stewart, John F.

Stewart, Jos. B.

Stimson, Fancher
Street, A. W.

Street, Jos. H. D.

Street, Jos. M.

Street, W. B.

Summers, Laurel

Swalm, Albert W.

Sweet, B. S.

Taylor, Charles G.

Taylor, Hawkins

Territorial Governors

Tillinghast, B. F.

Todd, John

'Tolles, C. W.

Tuttle, James M.

Twombly, Voltaire $\mathbf{P}$.

Tyler, Loren S.

Union I.cague of $\Lambda$ merica

Union League of East Des Moines

United Brethren Church in Christ

United Brethern in Christ

Van Antwerp, V.

Van Hyning, $\mathbf{T}$.

Van Winkle, A. S.

Vattemare, Alexander

Waite, J. I.

Walker, Margaret Coulson

Walker, Warren

Watson, Thomas E.

Weaver, James B.

Weaver, Silas $M$.

Whitcomb, Selden S.

White, Charles A.

White, Gilbert

Williams, Jesse

Williamson, James A.

Wilson, George

Wilson, James F.

Wilson, Lou

Wilson, 'Thomas

Wilson, William Duane

Wilson, Woodrow

Winslow, Edward F.

Wright, Carroll

Wright, George G.

Wright, James

Young, Lafayette 
Copyright of Annals of Iowa is the property of State of Iowa, by \& through the State Historical Society of Iowa and its content may not be copied or emailed to multiple sites or posted to a listserv without the copyright holder's express written permission. However, users may print, download, or email articles for individual use. 